\title{
The evolution of diabetes from prediabetes*
}

\author{
T. S. DANOWSKI \\ M.D. \\ Professor of Medicine, University of Pittsburgh, \\ Chief of Medicine, Magee Women's Hospital, Pittsburgh, Pennsylvania, U.S.A.
}

\begin{abstract}
Summary
Temporary stress-induced undue hyperglycaemia following an oral carbohydrate load taken during hospitalization is being tested as a possible indicator of prediabetes.

Observations in patients 15 months after hospitalization have permitted us to compare the blood sugar, insulin and growth hormone patterns evoked by an oral glucose load before and after glucose intolerance has appeared, viz. to speculate upon the evolution of diabetes from prediabetes. Though the numbers of such instances are as yet limited, they already suggest several possible sequences. Thus, our data support the concept that glucose intolerance, in addition to stemming from a decrease in insulin levels, can develop with true increases or with no evident decrease in the insulin responses to oral glucose.

The simplified in-hospital carbohydrate tolerance test employed in assembling groups of possibly prediabetic individuals is also an efficient means of detecting permanent glucose intolerance of the diabetes mellitus type.
\end{abstract}

\section{Introduction}

Opportunities to characterize blood sugar and serum insulin and growth hormone patterns and other indices prior to the appearance of persistent glucose intolerance of the diabetes mellitus type are few in number. We have, therefore, undertaken a study of a large number of persons to test the hypothesis that transient undue hyperglycaemia during hospitalization is a clue to the presence of diabetes or prediabetes.

\section{Materials and methods}

The general outline of the project is shown in Table 1 .

A screening type carbohydrate tolerance test [75 $\mathrm{g}$ in a cola-type drink (Danowski et al., 1966)] was performed during hospitalization. No attempt

\footnotetext{
* This work was presented on 4 October 1969 as the Twentieth Annual Banting Memorial Lecture before the British Diabetic Association and the British Paediatric Association; London, England.
}

TABLE 1. Evolution of diabetes from prediabetes

I. Screening cola tolerance test $(75 \mathrm{~g})$ in hospital

II. Initial oral GTT:

2-3 months after hospitalization

$1.75 \mathrm{~g} / \mathrm{kg}$ body weight

Venous blood sugar at $0, \frac{1}{2}, 1,2,3,4$ and $5 \mathrm{hr}$

Serum insulin and growth hormone during OGTT

* GTS o-2 hr $\left\{\begin{array}{l}<500 \\ 501-650 \\ >650\end{array}\right.$

III. Second OGTT in GTS $0-2$ hr groups

15 months after hospitalization

501-650

$<500$

IV. Third, fourth etc., OGTT

Schemae of in-hospital screening for glucose intolerance followed by a second oral glucose tolerance test two to three months later and at yearly intervals thereafter.

* GTS ${ }_{0-2} \mathrm{hr}=$ Sum of venous blood sugar levels at $0, \frac{1}{2}, 1$ and $2 \mathrm{hr}$ of OGTT.

was made to select patients for the screening test in a systematic manner because of the many variables involved, i.e. the need for obtaining the permission of the patient and the physician, the work load of laboratory and nursing personnel, the higher priority of other testing procedures scheduled during that admission, etc. Though the patient population varied as to age, sex and body weight, each individual tested was on an ordinary diet and either in the pre-operative or in the convalescent phase. None of the patients was febrile or bed-fast at the time of the test. Note was taken of all current medications, including those such as thiazides or cortisol-type steroids known to influence glucose tolerance. To simplify the screening procedure, we limited sampling to a single specimen of venous blood obtained at the 1-hr point following the carbohydrate drink. This time interval was selected after preliminary studies had indicated that undue hyperglycaemia present at the 2 -hr point is almost always accompanied by undue elevations of the 1-hr blood sugar value. 
The patients were divided into three groups, viz. those with 1-hr blood sugar values in the screening test at $180 \mathrm{mg} / 100 \mathrm{ml}$ or higher, those who were between 160 and $179 \mathrm{mg} / 100 \mathrm{ml}$, and those at $159 \mathrm{mg} / 100 \mathrm{ml}$ or less. Representatives selected at random from each of these three groups were examined with our standard oral glucose tolerance test some 2-3 months after hospitalization.

In the standard tolerance test, glucose was taken by mouth as a $50 \%$ solution in water at a dosage of $1.75 \mathrm{~g} / \mathrm{kg}$ of body weight. Samples of venous blood obtained at the $0, \frac{1}{2}, 1,2,3,4$ and $5 \mathrm{hr}$ of the test were analysed for levels of true glucose in blood (Hagedorn \& Jensen, 1923) and of immuno-assayable insulin and growth hormone in serum (Morgan, 1966). The results of each test were evaluated on the basis of the glucose tolerance sum for $2 \mathrm{hr}$ (the sum of the blood sugar levels at $0, \frac{1}{2}, 1$ and $2 \mathrm{hr}$, i.e. the $\mathrm{GTS}_{0-2} \mathrm{hr}$ ) in use in this laboratory (Danowski, unpublished data 1969), as well as the criteria of the United States Public Health Service (O'Sullivan \& Mahan, 1968), World Health Organization (McDonald, Hoet \& Butterfield, 1965), British Diabetic Association (FitzGerald \& Keen, 1964), and those of Fajans \& Conn (1959). Studies in this laboratory (Danowski, unpublished data 1969) indicate that in a large group of control subjects in whom the $\mathrm{GTS}_{0-2} \mathrm{hr}$ value is 500 or less, one can expect that $98 \cdot 5-100 \%$ of the tests would be deemed to be entirely normal by the various criteria cited. On the other hand, when the GTS $_{0-2}$ hs value is 651 or higher, our experience indicates that the blood sugar levels recorded during the oral glucose tolerance include $2-\mathrm{hr}$ values of $140 \mathrm{mg} / 100 \mathrm{ml}$ or higher in $95 \%$ of the test population, 2 -hr values between 120 and $140 \mathrm{mg} / 100 \mathrm{ml}$ in another $4 \%$, and 1 -hr levels of $180 \mathrm{mg} / 100 \mathrm{ml}$ or higher in virtually $100 \%$ (Danowski, unpublished data 1969). We have, therefore, selected the following tentative criteria for classifying the results of our standard oral glucose tolerance tests performed in follow-up of the inhospital cola-type tolerance:

$$
\begin{array}{lcl}
\text { GTS }_{0-2} \mathrm{hr} & >500: & \begin{array}{l}
\text { unimpaired glucose } \\
\text { tolerance, } \\
\text { equivocal glucose } \\
\text { tolerance, and }
\end{array} \\
\text { GTS }_{0-2} \mathrm{hr} & 501-650 & \begin{array}{l}
\text { impaired glucose } \\
\text { tolerance. }
\end{array}
\end{array}
$$

It is to be emphasized that these are tentative criteria selected solely for the purpose of testing a hypothesis.

Those patients who were found to have persistent marked glucose intolerance in the test performed 2-3 months following hospitalization were referred to their physicians for treatment. The others, patients with unimpaired or equivocal oral glucose tolerance tests, were admitted into the prospective study and scheduled for repeat oral tolerance tests at annual intervals.

Levels of serum pro-insulin (Steiner et al., 1968; Roth, Gorden \& Pastan, 1968; Danowski, unpublished data 1969) at the 2-hr point of our standard oral glucose tolerance test were measured in a series of subjects whose oral glucose tolerance had been characterized as indicated above and in two subjects in our prospective study in whom glucose tolerance was found to be definitely decreased in the test performed 15 months after hospitalization.

\section{Results}

In-hospital screening test for undue hyperglycaemia

A total of 4096 of the cola-type screening tests has been performed during the hospitalization of patients ranging in age from 20 to 75 years. The distribution of the 1-hr venous blood sugar levels in these tests is shown in Table 2. Though not indicated in the table, the higher blood sugar values

TABLE 2. Results of in-hospital cola tolerance tests

\begin{tabular}{lrr}
\hline 1 hr blood sugar & \multicolumn{2}{c}{ Patients } \\
$(\mathrm{mg} / 100 \mathrm{ml})$ & No. & $\%$ \\
\hline 200 & 324 & 8 \\
$200-219$ & 320 & 8 \\
$180-199$ & 415 & 10 \\
$160-179$ & 630 & 15 \\
$<160$ & 2,407 & 59 \\
Total & 4,096 & \\
\hline
\end{tabular}

Seventy-five grams of carbohydrate were administered in a cola-type drink to 4096 patients and true blood glucose was measured at the $1-\mathrm{hr}$ point.

occurred more often in the older patients and in those with obesity (arbitrarily defined for purposes of comparisons as a body weight in excess of $145 \mathrm{lb}$ in women and in excess of $180 \mathrm{lb}$ in men).

\section{Initial post-hospitalization oral glucose tolerance test}

To date 696 of the 4096 patients in whom the in-hospital cola-type test was performed have been re-examined at least once with our standard oral glucose tolerance. Each test was scheduled during an out-patient visit 2-3 months after discharge from the hospital, or later, when convalescence had been completed.

The results of the 696 tolerance tests performed in the initial post-hospitalization visit, 2 or more months after discharge, are summarized in Table 3 in terms of the GTS $_{0-2} \mathrm{hr}$ values. It is evident that abnormal glucose tolerance tests $\left(\mathrm{GTS}_{0-2} \mathrm{hr}\right.$ $>650$ ) occur most often in persons in whom the 1-hr blood sugar level in the cola-test was $180 \mathrm{mg} /$ $100 \mathrm{ml}$ or higher. 
TABLE 3. Results of in-hospital cola tolerance and initial OGTT

\begin{tabular}{|c|c|c|c|c|c|c|}
\hline \multicolumn{7}{|c|}{ Blood sugar } \\
\hline \multirow{3}{*}{$\begin{array}{l}\geqslant 180 \\
323 \text { total } \\
\left(54^{\circ} \%\right)\end{array}$} & \multirow{3}{*}{$\begin{array}{l}\text { GTS }<500 \ldots \\
\text { GTS } 501-650 \\
\text { GTS }>650 \ldots\end{array}$} & $\ldots$ & .. & $116(36 \%)$ & \multirow[b]{2}{*}{$159(49 \%)$} & \multirow[b]{3}{*}{$48(15 \%)$} \\
\hline & & . & $\cdots$ & . $\quad \cdots$ & & \\
\hline & & . & . & . & . $\quad \cdots$ & \\
\hline \multirow{3}{*}{$\begin{array}{l}160-179 \\
129 \text { total } \\
(22 \%)\end{array}$} & \multirow{3}{*}{$\begin{array}{l}\text { GTS }<500 \ldots \\
\text { GTS } 501-650 \\
\text { GTS }>650 \ldots\end{array}$} & . & . & $91(71 \%)$ & \multirow[b]{2}{*}{$35(27 \%)$} & \\
\hline & & . & . & . $\quad \cdots$ & & \\
\hline & & . & . & .. & . $\quad$. & $3(2 \%)$ \\
\hline \multirow{3}{*}{$\begin{array}{l}<160 \\
144 \text { total } \\
(24 \%)\end{array}$} & \multirow{3}{*}{$\begin{array}{l}\text { GTS }<500 \ldots \\
\text { GTS } 501-650 \\
\text { GTS }>650 \ldots\end{array}$} & .. & $\cdots$ & $92(64 \%)$ & \multirow[b]{2}{*}{$47(33 \%)$} & \\
\hline & & $\ldots$ & . & . $\quad \ldots$ & & \\
\hline & & . & . & .. & .. & $5(3 \%)$ \\
\hline
\end{tabular}

The initial standard oral glucose tolerance test performed on 596 patients provided evidence of glucose intolerance in $15 \%$ of those with $1 \mathrm{hr}$ in-hospital screening blood sugars of $180 \mathrm{mg} / 100 \mathrm{ml}$ or higher.

\section{The evolution of diabetes from pre-diabetes}

To date we have re-examined, at the 15 -month point following hospitalization, seventy-eight of the patients who had undue hyperglycaemia during the in-hospital cola test and a normal or an indeterminate standard oral glucose tolerance test during the initial evaluation performed some 2 or 3 months after leaving the hospital. Our findings in these seventy-eight patients are summarized in Table 4. Thus, at the 15-month follow-up, the glucose toler-

TABLE 4. Results of second follow-up OGTT 15 months after hospitalization (GTS $0-2 \mathrm{hr}<500$ or 501-650 at first follow-up)

\begin{tabular}{|c|c|c|}
\hline & $\begin{array}{c}\text { GTS }_{0-2} \text { hr } \\
\text { (second OGTT) }\end{array}$ & $\begin{array}{c}\text { No. of } \\
\text { patients }\end{array}$ \\
\hline $\begin{array}{l}\text { GTS } 0-2 \mathrm{hr} \\
<500 \text { in first OGTT } \\
\text { (32 patients) }\end{array}$ & $\left\{\begin{array}{l}<500 \\
501-650 \\
>650\end{array}\right.$ & $\begin{array}{c}21(66 \%) \\
10(31 \%) \\
1(3 \%)\end{array}$ \\
\hline $\begin{array}{l}\text { GTS }_{0-2} \mathrm{hr} \\
501-650 \text { in first OGTT } \\
\text { (46 patients) }\end{array}$ & $\left\{\begin{array}{l}<500 \\
501-650 \\
>650\end{array}\right.$ & $\begin{array}{r}7(15 \%) \\
28(61 \%) \\
11(24 \%)\end{array}$ \\
\hline
\end{tabular}

In the second standard glucose tolerance test performed approximately 15 months after hospitalization, $24 \%$ of the patients who were in the indeterminate group with respect to glucose tolerance in the first test were found now to have definite glucose intolerance in the second test.

ance had decreased in about one-third of the patients $(31+3 \%=34 \%)$ who had no glucose intolerance $\left(\mathrm{GTS}_{0-2} \mathrm{hr}<500\right)$ at the initial 2-3 month evaluation. Also, the tolerance for glucose decreased (i.e. GTS $_{0-2} \mathrm{hr}$ became $>650$ ) in about one-quarter of the group whose initial 2-3 month tolerance was in the indeterminate or equivocal range $\left(\mathrm{GTS}_{0-2} \mathrm{hr}\right.$ value of 501-650). In other words, definite glucose tolerance abnormalities $\left(\mathrm{GTS}_{0-2} \mathrm{hr}>650\right)$ had developed in twelve out of seventy-eight patients during the year following the initial post-hospital evaluations which categorized their glucose intolerance as unimpaired or equivocal.

\section{Serum insulin changes}

The data in Table 5 are derived from patients in whom definite glucose intolerance had developed between the first evaluation ( 2 or 3 months after hospitalization) and the second one (15 months post-hospitalization).

In patient V.N., the $\mathrm{GTS}_{0-2}$ hr value of 420 indicated unimpaired tolerance in the initial evaluation and definitely impaired tolerance $\left(\mathrm{GTS}_{0-2} \mathrm{hr}\right.$ at 743) 1 year later. The ( $\triangle$ blood sugar $) /(\triangle$ insulin $)$ $0-2 \mathrm{hr}$ values (the ratio of the sum of the increments in blood sugar to the sum of the increments in the serum insulin at the $\frac{1}{2}-, 1-$ and 2 -hr points of the test) at these two times indicate a flagging of insulin output in relation to the hyperglycaemia.

In the next six patients the initial post-hospitalization oral glucose tolerance was in the equivocal or indeterminate range $\left(\mathrm{GTS}_{0-2} \mathrm{hr}\right.$ value of 501-650) with the 15th month test in the abnormal zone ( $>650)$. The ( $\triangle$ blood sugar) $/(\triangle$ insulin) $0-2 \mathrm{hr}$ data from the 15th month test indicate that the insulin levels relative to the degree of hyperglycaemia had become lower in G.S. and M.J., remained unchanged in E.L. and S.K., and clearly increased in A.M. and E.F. Hence, the findings in E.L., S.K., A.M. and E.F. indicate that in adults the transition from a normal or equivocal to a clearly abnormal glucose tolerance may occur despite maintenance of, or even enhancement of, the insulin responses to glucose.

On the other hand, in patients V.N., G.S. and M.J. the insulin response was diminished when definite glucose intolerance had appeared: the ( $\triangle$ blood sugar $) /(\triangle \text { insulin })_{0-2} \mathrm{hr}$ ratio was increased at the 15-month test in each of these patients.

A similar but more striking decrease in insulin levels following glucose was observed in J.V., a sibling of a juvenile diabetic, who had not been hospitalized but did have a normal initial oral glucose tolerance test. It is to be noted that in a 
TABLE 5. Ratio of increments in blood sugar to increments in insulin in patients with unimpaired, equivocal and definitely impaired glucose tolerance.

\begin{tabular}{|c|c|c|c|c|c|}
\hline Patient & Age (years) & Sex & Weight (lb) & GTS $_{0-2} \mathrm{hr}$ & $\begin{array}{l}\text { ( } \triangle \text { blood sugar }) / \\
(\triangle \text { insulin })_{0-2} \mathrm{hr}\end{array}$ \\
\hline V.N. & $\begin{array}{l}51 \\
52\end{array}$ & $\mathbf{F}$ & $\begin{array}{l}143 \\
187\end{array}$ & $\begin{array}{l}420 \\
743\end{array}$ & $\begin{array}{l}0.90 \\
1.90\end{array}$ \\
\hline G.S. & $\begin{array}{l}59 \\
60\end{array}$ & $\mathbf{F}$ & $\begin{array}{l}238 \\
257\end{array}$ & $\begin{array}{l}514 \\
752\end{array}$ & $\begin{array}{l}0.51 \\
0.95\end{array}$ \\
\hline M.J. & $\begin{array}{l}47 \\
48\end{array}$ & $\mathbf{F}$ & $\begin{array}{l}234 \\
230\end{array}$ & $\begin{array}{l}516 \\
702\end{array}$ & $\begin{array}{l}0.33 \\
0.74\end{array}$ \\
\hline E.L. & $\begin{array}{l}54 \\
55\end{array}$ & $\mathbf{M}$ & $\begin{array}{l}168 \\
175\end{array}$ & $\begin{array}{l}592 \\
862\end{array}$ & $\begin{array}{l}0 \cdot 34 \\
0 \cdot 31\end{array}$ \\
\hline S.K. & $\begin{array}{l}33 \\
34\end{array}$ & $\mathbf{F}$ & $\begin{array}{l}219 \\
225\end{array}$ & $\begin{array}{l}521 \\
726\end{array}$ & $\begin{array}{l}0.68 \\
0.64\end{array}$ \\
\hline A.M. & $\begin{array}{l}63 \\
64\end{array}$ & $\mathbf{F}$ & $\begin{array}{l}191 \\
190\end{array}$ & $\begin{array}{l}524 \\
744\end{array}$ & $\begin{array}{l}1.00 \\
0.70\end{array}$ \\
\hline E.F. & $\begin{array}{l}62 \\
63\end{array}$ & $\mathbf{F}$ & $\begin{array}{l}135 \\
112\end{array}$ & $\begin{array}{l}541 \\
945\end{array}$ & $\begin{array}{l}2 \cdot 80 \\
1 \cdot 30\end{array}$ \\
\hline J.V. & $\begin{array}{l}11-9 \\
12-11\end{array}$ & $\mathbf{F}$ & $\begin{array}{l}102 \\
108\end{array}$ & $\begin{array}{r}431 \\
1004\end{array}$ & $0 \cdot 17$ \\
\hline
\end{tabular}

The $\Delta$ blood sugar/ $\Delta$ insulin is the ratio of the sum of the increments of blood sugar at the one-half, 1- and 2-hr points to the sum of increments in insulin at the same time intervals.

TABLE 6. Growth hormone profile*

\begin{tabular}{|c|c|c|c|c|c|c|c|}
\hline Patient & $\begin{array}{c}\text { Age } \\
\text { (years) }\end{array}$ & Sex & $\begin{array}{l}\text { Time out of } \\
\text { hospital } \\
\text { (months) }\end{array}$ & $\begin{array}{l}\text { Weight } \\
\text { (lb) }\end{array}$ & Fasting GH & $\begin{array}{c}\text { GH } \\
\text { Peak }\end{array}$ & $\underset{0-5 \mathrm{hr}}{\text { GH sum }}$ \\
\hline V.N. & 51 & $\mathbf{F}$ & $\begin{array}{r}3 \\
16\end{array}$ & $\begin{array}{l}143 \\
187\end{array}$ & $\begin{array}{l}2 \cdot 0 \\
1 \cdot 2\end{array}$ & $\begin{array}{l}7 \cdot 0 \\
2 \cdot 5\end{array}$ & $\begin{array}{l}21 \\
15\end{array}$ \\
\hline G.S. & 59 & $\mathbf{F}$ & $\begin{array}{r}3 \\
15\end{array}$ & $\begin{array}{l}238 \\
257\end{array}$ & $\begin{array}{l}2 \cdot 8 \\
1.6\end{array}$ & $\begin{array}{l}3.8 \\
3.0\end{array}$ & $\begin{array}{l}14 \\
17\end{array}$ \\
\hline M.J. & 47 & $\mathbf{F}$ & $\begin{array}{r}3 \\
16\end{array}$ & $\begin{array}{l}234 \\
230\end{array}$ & $\begin{array}{l}1.0 \\
2.7\end{array}$ & $\begin{array}{l}4 \cdot 9 \\
2 \cdot 7\end{array}$ & $\begin{array}{l}18 \\
14\end{array}$ \\
\hline E.L. & 54 & $\mathbf{M}$ & $\begin{array}{r}3 \\
15\end{array}$ & $\begin{array}{l}168 \\
175\end{array}$ & $\begin{array}{l}1 \cdot 0 \\
4 \cdot 2\end{array}$ & $\begin{array}{l}2 \cdot 5 \\
4 \cdot 2\end{array}$ & $\begin{array}{l}14 \\
23\end{array}$ \\
\hline S.K. & 33 & $\mathbf{F}$ & $\begin{array}{r}3 \\
15\end{array}$ & $\begin{array}{l}219 \\
225\end{array}$ & $\begin{array}{l}1.5 \\
1.5\end{array}$ & $\begin{array}{l}3 \cdot 5 \\
2 \cdot 5\end{array}$ & $\begin{array}{l}19 \\
15\end{array}$ \\
\hline A.M. & 63 & $\mathbf{F}$ & $\begin{array}{r}3 \\
15\end{array}$ & $\begin{array}{l}191 \\
190\end{array}$ & $\begin{array}{l}2.9 \\
1.9\end{array}$ & $\begin{array}{l}2 \cdot 7 \\
2 \cdot 8\end{array}$ & $\begin{array}{l}14 \\
15\end{array}$ \\
\hline E.F. & 62 & $\mathbf{F}$ & $\begin{array}{r}3 \\
15\end{array}$ & $\begin{array}{l}135 \\
112\end{array}$ & $\begin{array}{r}7 \cdot 8 \\
12 \cdot 7\end{array}$ & $\begin{array}{r}9 \cdot 8 \\
15 \cdot 5\end{array}$ & $\begin{array}{l}27 \\
51\end{array}$ \\
\hline J.V. & $11 \frac{3}{4}$ & $\mathrm{~F}$ & $\begin{array}{r}3 \\
19\end{array}$ & $\begin{array}{l}102 \\
108\end{array}$ & $\begin{array}{r}7 \cdot 0 \\
10 \cdot 2\end{array}$ & $\begin{array}{r}1 \cdot 5 \\
10 \cdot 2\end{array}$ & $\begin{array}{l}34 \\
41\end{array}$ \\
\hline
\end{tabular}

* Recorded prior to and during oral glucose tolerance tests performed 3 months and 15-19 months after hospitalization. GH sum or growth hormone sum is the sum of the serum GH levels at the $0, \frac{1}{2}$, $1,2,3,4$ and $5 \mathrm{hr}$ of the tolerance test.

group of peers studied at the same time, the insulin responses of this child exceeded all others (Danowski et al., 1969). Once diabetes was present, glucose loading did not evoke a rise in serum insulin.

Growth hormone and pro-insulin in persons with decreases in glucose tolerance of recent onset

From Table 6 it is clear that the appearance of definite glucose intolerance in this small group of patients was not associated with a discernible pattern of change in serum growth hormone levels prior to or during an oral glucose tolerance.

Measurements of pro-insulin (Steiner et al., 1968; Roth et al., 1968; Danowski, unpublished data 1969) at the 2-hr point of the second standard oral glucose tolerance in patient S.K. yielded a level within the range of values recorded in our laboratory in persons with glucose tolerance sums of $<500,501-650$ or $>650$. However, in patient E.L. the pro-insulin level may be increased at $56 \cdot 3 \mu$-units/ml (Table 7). 
TABLE 7. Serum pro-insulin at 2 -hr point of oral glucose tolerance test $(1 \cdot 75 \mathrm{~g} / \mathrm{kg})$

\begin{tabular}{lccc}
\hline Subjects & GTS 0-2 hr & $\begin{array}{c}\text { Pro-insulin } \\
\text { at } 2 \mathrm{hr} \\
(\mu \text {-units/ml })\end{array}$ & $\begin{array}{c}\text { Total insulin } \\
\text { at } 2 \mathrm{hr} \\
(\mu \text {-units/ml })\end{array}$ \\
\hline Controls & $<500$ & $16 \cdot 2 \pm 10 \cdot 6(23)$ & $62 \cdot 9 \pm 36(23)$ \\
Controls & $501-650$ & $12 \cdot 4 \pm 10 \cdot 6(22)$ & $* 121 \cdot 6 \pm 70 \cdot 9(22)$ \\
Controls & $>650$ & $20 \cdot 1 \pm 14 \cdot 3(10)$ & $* 301 \cdot 2 \pm 298 \cdot 3(10)$ \\
\hline Patient E.L. & 862 & $56 \cdot 3$ & 563 \\
Patient S.K. & 726 & $9 \cdot 3$ & 233 \\
\hline
\end{tabular}

Serum pro-insulin appears to be high in patient E.L. and normal in patient S.K. at the 2-hr point of the oral glucose tolerance test performed after definite glucose intolerance had developed.

* Difference between this mean and corresponding value in GTS $_{0-2} \mathrm{hr}<500$ group is statistically significant.

\section{Discussion}

In this search for prediabetes, we have concentrated on those patients who developed undue hyperglycaemia during the cola-type in-hospital tolerance test and a normal standard oral glucose tolerance test at the 2 or 3 month point following discharge from the hospital. Such a sequence is compatible with the hypothesis that the stresses of hospitalization can result in undue hyperglycaemia and that the hyperglycaemia occurs more often and to a greater degree in persons who are genetically or otherwise constituted as prediabetic. Once the stresses are removed, the tendency to undue hyperglycaemia then disappears as the individual reverts to his previous state of prediabetes and normal glucose tolerance.

It seems reasonable to suggest that in the instances in which the initial post-hospitalization glucose tolerance was entirely normal and the 15-month test was clearly abnormal, we can with considerable assurance speak of the evolution of diabetes from prediabetes. On the other hand, in those with an indeterminate or equivocal tolerance test at the initial 2-3 month post-hospitalization evaluation and a definitely abnormal glucose tolerance 1 year later, we are dealing with deterioration of tolerance in a person with a prior equivocal inability to dispose of a glucose load.

It appears that in several of our adult patients the advent of definite glucose intolerance of the diabetes mellitus type cannot be related to decreased levels of serum insulin. Judging from the ratios of the increment in insulin in relation to the rise in blood sugar in these patients, the insulin responses were either enhanced and a true hyperinsulinaemia developed or glucose intolerance appeared and became accentuated without a decrease in the insulin responses to an oral glucose load. Several tentative interpretations of these findings come to mind. First, it is possible that even though the glucose loads taken at each tolerance test were of the same general magnitude, absorption was more rapid and resulted in increased hyperglycaemia in the second test. Second, it is conceivable that in the test performed 15 months after hospitalization, the oral glucose load was for some reason supplemented by glucose of endogenous, i.e. glycogenolytic or gluconeogenic, origin. Third, it may be that the insulin secreted at the second test did not possess its usual hypoglycaemic effect either because the insulin molecule was defective or represented pro-insulin or some other variant and/or its hypoglycaemic action was partially cancelled by growth hormone or other anti-insulin factors in serum or tissues. Fourth, it could be that the normal, or increased, levels of insulin recorded in the second test masked an actual deficiency of insulin secretion and turnover perhaps as a result of diminished transfer to tissues. The occurrence of the last of these possibilities is supported by the insulin clearance studies of Butterfield, Garratt \& Whichelow (1963).

Our data appear to exclude changes in growth hormone as a variable productive of decreased glucose tolerance in the face of enhanced or unchanged insulin levels, but the number of our observations is still small. We do not yet have enough data on pro-insulin to permit generalization. Also, we do not know that glucose absorption rates, contributions of endogenous glucose, levels of antiinsulin factors other than growth hormone in plasma or in tissues, or that insulin secretion, removal, or effects have or have not changed. Studies of these adult patients have provided us, however, with data supportive of the concept that diabetes can and does develop in adults despite a true increase, or at least no decrease, in the levels of apparent or immuno-assayable insulin present in serum after oral glucose. This may not, however, be a universal pattern. Thus, the finding of diminished insulin increments in blood sugar in some of our patients with definite glucose intolerance of one year's duration or less suggests that this may be the 
sequence in some persons or that the true hyperinsulinaemia noted in some individuals is a transient phase which may disappear within a year.

The insulin responses to glucose in our one juvenile patient measured before she developed diabetes exceeded those of most or all of the control subjects (Danowski et al., 1969). This raises the possibility that some children also pass through a hyperinsulinaemic or dysinsulinaemic phase before exhaustion of the pancreatic islets occurs.

As further data accumulate, it should be possible to assess, in this group of prediabetic individuals who subsequently develop diabetes, the value of indices other than the serum insulin, growth hormone and inorganic phosphate responses to glucose. These indices might include, among others, family history, physical characteristics, body weight, blood pressure, electrocardiographic patterns, perception of vibration and levels of urea, creatinine, uric acid, cholesterol and triglycerides in serum. It may be that one or more of these data bits could sharpen the criteria for identification of those destined to develop diabetes. It may well be true, as some say, that at this time little can be gained in terms of the person's welfare by diagnosing the diabetes as early as possible. However, this is a point worthy of study.

It might be that the most valuable information which will come from such a prospective study will be the opportunity to document, within a reliable span of time, the date of onset of a specific instance of diabetes. This information is almost always lacking in adult-onset diabetes and yet the duration of diabetes is a critical item in assessing the hazards of diabetes and the merits of treatment programmes. Also, knowledge of the date of onset of diabetes is essential in any attempts to determine whether or not mild types of diabetes, or the examples of socalled latent or chemical diabetes, or the glucose intolerance of old age are or are not hazards to health and should or should not be treated.

There are important immediate products of a prospective study of the type herein described. Thus, we have noted a marked increase in the attention paid by physicians and hospital personnel to the possibility of diabetes, certainly an indis- pensible feature of an adequate assessment of any patient. Also, we have uncovered a number of previously unrecognized instances of diabetes. To date, this has occurred in our series at a rate which exceeds that recorded in community or other diabetes detection drives.

Finally, should techniques be developed for the precise recognition of the prediabetic state, manipulations designed to postpone the advent or to ameliorate the intensity of diabetes could be undertaken.

\section{References}

Butterfield, W.J.H., Garratt, C.J. \& Whichelow, M.J. (1963) Peripheral hormone action: Studies on the clearance and effect of $\left.{ }^{[31} \mathrm{I}\right]$ iodo-insulin in the peripheral tissues of normal, acromegalic and diabetic subjects. Clinical Science, $24,331$.

DaNoWSKi, T.S., Moses, C., WeIR, T.F., WingerT, J.P., MAcDuffee, R.C. \& TAYloR, J.S., JR (1966) Diabetes detection in hospitalized patients. Pennsylvania Medicine, 69, 29.

Danowski, T.S., Lombardo, Y.B., Mendelsohn, L.V., Corredor, D.G., Morgan, C.R. \& SABEH, G. (1969) Insulin patterns prior to and after onset of diabetes. Metabolism, 18, 731.

FaJANS, S.S. \& CoNN, J.W. (1959) Early recognition of diabetes mellitus. Annals of the New York Academy of Sciences, 82, 208.

FitzGerald, M.G. \& Keen, H. (1964) Diagnostic classification of diabetes. British Medical Journal, 1, 1568.

HAGEDORN, H.C. \& JENSEN, B.N. (1923) Zur Mikrobestimmung des Blutzuckers mittels Ferricyanid. Biochemische Zeitschrift, 135, 46.

MCDonald, G.W., Hoet, J.P. \& ButTerfield, W.J.H. (1965) Diabetes Mellitus: Report of a WHO Expert Committee. World Health Organization Technical Report Series, 310.

MoRGAN, C.R. (1966) Immunoassay of human insulin and growth hormone simultaneously using I-131 and I-125 tracers. Proceedings of the Society for Experimental Biology and Medicine, 123, 230.

O'Sullivan, J.B. \& Mahan, C.M. (1968) Prospective study of 352 young patients with chemical diabetes. New England Journal of Medicine, 278, 1038.

Roth, J., Gorden, P. \& Pastan, I. (1968) 'Big Insulin': A new component of plasma insulin detected by immunoassay. Proceedings of the National Academy of Science, 61, 138.

Steiner, D.F., Hallund, O., Rubenstein, A., Cho, S. \& BAYLISS, C. (1968) Isolation and properties of pro-insulin, intermediate forms, and other minor components from crystalline bovine insulin. Diabetes, 17, 725. 